\title{
The N-Terminal Domain of Nogo-A Inhibits Cell Adhesion and Axonal Outgrowth by an Integrin-Specific Mechanism
}

\author{
Fenghua $\mathrm{Hu}^{1,2}$ and Stephen M. Strittmatter ${ }^{1,2}$ \\ ${ }^{1}$ Program in Cellular Neuroscience, Neurodegeneration and Repair, Department of Neurology, Yale University School of Medicine, New Haven, Connecticut \\ 06510, and ${ }^{2}$ Department of Neurology, Yale University School of Medicine, New Haven, Connecticut 06520
}

\begin{abstract}
Myelin-derived Nogo-A protein limits axonal growth after CNS injury. One domain binds to the Nogo-66 receptor to inhibit axonal outgrowth, whereas a second domain, Amino-Nogo, inhibits axonal outgrowth and cell adhesion through unknown mechanisms. Here, we show that Amino-Nogo inhibition depends strictly on the composition of the extracellular matrix, suggesting that Amino-Nogo inhibits the function of certain integrins. Amino-Nogo inhibition can be partially overcome by antibodies that activate integrin $\beta 1$ or by the addition of $\mathrm{Mn}^{2+}$, an integrin activator. Furthermore, Amino-Nogo reduces focal adhesion kinase activation by fibronectin. Analysis of various cell lines reveals that $\alpha \mathrm{v} \beta 3, \alpha 5$, and $\alpha 4$ integrins are sensitive to Amino-Nogo, but $\alpha 6$ integrin is not. Both $\alpha \mathrm{v}$ and $\alpha 5$ integrins have widespread expression in adult brain and are found in axonal growth cones. Thus, inhibition of integrin signaling by Amino-Nogo contributes to the failure of CNS axon regeneration.
\end{abstract}

Key words: myelin; axon regeneration; spinal cord injury; outgrowth inhibitor; cell adhesion; integrin

\section{Introduction}

The adult mammalian CNS exhibits a severely limited degree of anatomical rearrangement in response to a range of perturbations. This fact leads to persistent clinical deficits after neurological injury by preventing significant nerve fiber regeneration. Among the factors limiting axonal growth in the adult CNS is myelin, and Nogo is one of the proteins produced by oligodendrocytes that inhibits axonal growth (Chen et al., 2000; GrandPre et al., 2000; Huber and Schwab, 2000; Liu et al., 2006). Alternative promoter usage and differential splicing of the nogo gene give rise to three major transcripts (Nogo-A, $-\mathrm{B}$, and $-\mathrm{C}$ ). The loop between the two hydrophobic domains of Nogo (Nogo66) is common to all three isoforms, and it binds to a glycosylphosphatidylinositol-linked receptor $(\mathrm{NgR})$ to inhibit axonal outgrowth (Fournier et al., 2001). Nogo-A contains a unique $\mathrm{N}$-terminal domain (Amino-Nogo) that has been shown to inhibit both axon growth and fibroblast spreading in vitro (Fournier et al., 2001; Oertle et al., 2003). However, the mechanisms of Amino-Nogo inhibition remain unknown. Studies have suggested the existence of a receptor or receptor complex on the surface of responsive fibroblasts and in the CNS, but the identity of the receptor has not been determined (Oertle et al., 2003). Despite this uncertainty about Amino-Nogo action, antibodies

Received March 8, 2007; revised Nov. 16, 2007; accepted Dec. 19, 2007.

This work was supported by grants to S.M.S. from the National Institutes of Health and a fellowship to F.H. from the Paralyzed Veterans of America Foundation. We thank Drs. Caroline Damsky (University of California at San Francisco, San Francisco, CA) and David Cheresh (University of California at San Diego, San Diego, CA) for providing CS1- $\beta 3$ cells, and Drs. Lingling Chen and Jane K. Relton from Biogenldec (Cambridge, MA) for providing VCAM-1, PS2, and Bio5192.

Correspondence should be addressed to Stephen M. Strittmatter, Department of Neurology, Yale University School of Medicine, New Haven, CT 06520. E-mail: stephen.strittmatter@yale.edu.

D0I:10.1523/JNEUROSCI.1068-07.2008

Copyright $\odot 2008$ Society for Neuroscience $\quad$ 0270-6474/08/281262-08\$15.00/0 directed against this domain have been effective in promoting recovery from neurological injury in rodent and primate preclinical studies (Bregman et al., 1995; Thallmair et al., 1998; Liebscher et al., 2005; Freund et al., 2006), and clinical trials of anti-Nogo-A antibodies are underway.

Here, we sought to define the molecular pathways by which Amino-Nogo inhibits cell spreading and neurite outgrowth. Identification of a high-affinity cell surface-binding protein is complicated by the observation that the ligand must be presented in a high-molecular-weight clustered form to exert biological activity, and by the fact that multiple cell types show equally robust Amino-Nogo responses. Because Amino-Nogo inhibits cell adhesion and integrins play a principal role as cell adhesion receptors, we examined an interaction between Amino-Nogo signaling and integrin signaling.

Integrins are cell surface glycoproteins composed of noncovalently linked $\alpha$ and $\beta$ heterodimers that mediate cell-cell and cell-extracellular matrix (ECM) interactions (Hynes, 1992). Integrin engagement of ECM ligands results in the formation of adhesion complexes that provide a coupling to the actin cytoskeleton that is necessary for cell spreading and for the force generation during growth cone advance (Suter and Forscher, 1998; Beningo et al., 2001). To date, 18 different $\alpha$ and 8 different $\beta$ mammalian integrin subunits have been identified to form 24 recognized $\alpha \beta$ heterodimers. The interaction between integrins and ligands are diverse because some integrins bind several different ligands and some ECM ligands also bind to multiple integrins. Focal adhesion kinase (FAK) becomes activated after integrin activation and has been shown to play a key role in growth cone dynamics and axon pathfinding (Robles and Gomez, 2006).

Here we show that Amino-Nogo binds to and selectively blocks signal transduction initiated by certain integrins. The widespread expression of Nogo-sensitive integrin subunits ac- 
counts for the presence of Amino-Nogo responses in diverse cell types. Identification of integrins as mediators of Amino-Nogo inhibition of axon growth provides a basis to develop alternate means to block Amino-Nogo effects.

\section{Materials and Methods}

Cell culture and reagents. COS-7, Jurkat, and CHO-K1 cells were obtained from American Type Culture Collection (Manassas, VA). HUVEC cells were obtained from cell culture facility at Yale University. CS1- $\beta 3$ cells were kindly provided by Dr. Caroline Damsky (University of California at San Francisco, San Francisco, CA) and Dr. David Cheresh (University of California at San Diego, San Diego, CA). Integrin $\beta 1$-activating antibodies and $\alpha 5$ - and $\alpha \mathrm{v} \beta 3$-blocking antibodies were purchased from Millipore (Billerica, MA). Fibronectin, vitronectin, and poly-D-lysine were purchased from Sigma-Aldrich (St. Louis, MO). Mouse laminin-1 was from Invitrogen. Collagen (type I, rat tail) was obtained from BD Biosciences (San Jose, CA). VCAM-1-Ig4 fusion protein, PS2 antibodies, and Bio5192 were kindly provided by Dr. Lingling Chen and Dr. Jane K. Relton from BiogenIdec (Cambridge, MA).

Recombinant $F c$ fusion protein production. For mammalian expression, human Amino-Nogo X fragment (nucleotides 540-2592) and $\Delta 20$ fragment (nucleotides 1704-2247) were cloned into pIg-tail expression system (Novagen, Madison, WI). Plasmids were transfected into HEK293T cells, and recombinant proteins were purified by protein A agarose (Sigma-Aldrich). For expression in insect cells, human Amino-Nogo X fragment (nucleotides 540-2592) and human Fc sequence were cloned in frame into pAcHLT-C baculovirus transfer vector (BD Biosciences). Baculoviruses expressing Amino-Nogo- $\mathrm{Fc}(\mathrm{Ng}-\mathrm{Fc})$ were generated, amplified, and used to infect $\mathrm{Sf} 9$ insect cells. $\mathrm{Ng}$-Fc was purified from the infected Sf9 cells by binding to Ni column (Invitrogen). Ng-Fc was dialyzed in PBS and clustered using goat anti-human IgG (Sigma-Aldrich) before the assays.

Cell adhesion assays. ECM molecules of indicated concentrations were coated on 96-well tissue culture dish (Falcon, Franklin Lakes, NJ) for 1-2 $\mathrm{h}$ at room temperature (RT). Wells were then blocked with PBS $+3 \%$ heat-inactivated BSA for $2 \mathrm{~h}$ at RT. Cells were trypsinized, washed with DMEM (Invitrogen), and plated in DMEM +25 mM HEPES. Clustered $\mathrm{Fc}$ or $\mathrm{Ng}$-Fc was added to the media at the time of plating. After $120 \mathrm{~min}$ of incubation, plates were washed three times with DMEM + HEPES before fixation and staining with Hoescht and rhodamine-phalloidin (Invitrogen). All data shown are mean $\pm \operatorname{SEM}(n=2-8)$.

FAK phosphorylation assay. After the adhesion assay, floating cells were collected and lysed together with attached cells in $50 \mathrm{~mm}$ Tris, $\mathrm{pH}$ 8.0, 150 $\mathrm{mm} \mathrm{NaCl}, 1 \%$ Triton X-100 with standard proteinase inhibitors and phosphatase inhibitors. To immunoprecipitate FAK, rabbit anti-FAK antibodies (Santa Cruz Biotechnology, Santa Cruz, CA; catalog \#c903) were incubated with the lysate followed by incubation with protein $\mathrm{A} / \mathrm{G}$ beads. After three washes, beads were boiled and subjected to SDS-PAGE. Mouse anti-FAK (Millipore) and rabbit anti-phospho-FAK (Tyr 397) antibodies (Sigma-Aldrich) were used to blot total FAK or phosphoFAK, respectively. Image J software was used to quantify intensities of the bands on immunoblot. Percentage of FAK activation were calculated by dividing phospho-FAK signal with total FAK signal and standardized by using BSA as $0 \%$ and PBS control as $100 \%$. Data shown are mean \pm SEM $(n=3)$. $p$ value was calculated using a two-tailed Student's $t$ test.

Neurite outgrowth assay. Dissociated embryonic day 10 (E10)-E11 chick DRG neurons in Neurobasal $+\mathrm{B} 27+\mathrm{NgF}$ media or postnatal day 6 (P6)-P10 rat DRG neurons in Neurobasal-A + B27 media were plated onto 96-well tissue culture dishes coated with indicated ECM substrates and grown for $16 \mathrm{~h}$. Clustered $\mathrm{Fc}$ or $\mathrm{Ng}-\mathrm{Fc}$ was added to the media at the time of plating. Neurons were fixed and stained with rabbit anti- $\beta$ III tubulin antibodies (Covance, Princeton, NJ). Neurite length was analyzed by the Imagexpress imaging system and software (MDS Analytical Technologies, Sunnyvale, CA). All data shown are mean \pm SEM $[n=$ 2-12 for chick dorsal root ganglia (cDRGs) and $n=6-18$ for rat dorsal root ganglia (rDRGs)].

Integrin staining. Rabbit polyclonal antibodies for integrin $\alpha 5$ and $\alpha \mathrm{v}$ were purchased from Millipore and used to stain dissociated E10-E11 chick DRG neurons or adult mouse brain sections.
Immunoprecipitation. Adult wild-type or nogoAB-/- (Kim et al., 2003) mouse brains were homogenized in $50 \mathrm{~mm}$ Tris, $\mathrm{pH} 8.0,150 \mathrm{~mm}$ $\mathrm{NaCl}$, and $1 \%$ Triton $\mathrm{X}-100$ with proteinase inhibitors and spun at $20,000 \times g$ for $20 \mathrm{~min}$. The soluble proteins were immunoprecipitated at $4^{\circ} \mathrm{C}$ using indicated antibodies, incubated with protein $\mathrm{A} / \mathrm{G}$ beads (Santa Cruz Biotechnology), and washed three times with 50 mm Tris, $\mathrm{pH} 8.0$, $150 \mathrm{~mm} \mathrm{NaCl}$, and $1 \%$ Triton X-100. The presence of Nogo in the immunoprecipitates was detected using rabbit anti-Nogo-A antibodies (Wang et al., 2002).

\section{Results}

\section{Amino-Nogo inhibits COS-7 adhesion on fibronectin}

To determine whether Amino-Nogo alters integrin signaling, we examined whether Amino-Nogo inhibition of cell adhesion can be modulated by different ECM substrates. We generated recombinant Amino-Nogo fragments fused to Fc because clustering has been shown to be important to Amino-Nogo activity (Fournier et al., 2001) and the Fc domain dimerizes by disulfide bonds. Surprisingly, we found that COS-7 adhesion on fibronectin, but not laminin or collagen, is inhibited by clustered Amino-Nogo (Fig. $1 A$ ). The X-fragment of Amino-Nogo (amino acids 181-864; $\mathrm{X}-\mathrm{Fc}$ ) is more inhibitory than the $\Delta 20$ fragment (amino acids $568-749$; 20-Fc) (Fig. 1), suggesting that there exists a more extended inhibitory domain in the $\mathrm{X}$ fragment beyond the $\Delta 20$ segment. Clustered Amino-Nogo X fragment fused to Fc (referred to as $\mathrm{Ng}-\mathrm{Fc}$ from here on) inhibits COS-7 adhesion on fibronectin with an $\mathrm{IC}_{50}$ of $\sim 40 \mathrm{~nm}$ (Fig. $2 \mathrm{~A}$ ). Amino-Nogo significantly inhibits COS-7 adhesion over a wide range of fibronectin concentrations, although the inhibition decreased at higher concentration of fibronectin (Fig. $2 B$ ). The dose-response curves for Amino-Nogo inhibition were determined to examine the possibility that lack of Amino-Nogo inhibition on laminin and collagen is caused by high concentration of laminin or collagen used in the initial assay. However, at all concentrations tested for collagen and laminin, Amino-Nogo is not inhibitory, with the possible exception of very low concentration of collagen (Fig. 2C,D).

Selective inhibition of adhesion by Amino-Nogo on one ECM substrate but not others might be mediated by selective AminoNogo interaction with ECM substrates or integrin receptor pathways. If Amino-Nogo interacts with ECM substrate directly, then Amino-Nogo inhibition would be expected to correlate best with ECM rather than with cell type. On the other hand, if AminoNogo alters the function of ECM receptors such as integrins, then Amino-Nogo inhibition would be expected to vary between cell types, because multiple integrins can mediate adhesion to any one ECM substrate, and different cell types use different integrins. We found that Amino-Nogo inhibits PC12 cell adhesion to laminin and collagen even though COS-7 adhesion to laminin and collagen is not altered by Amino-Nogo (data not shown). Thus, the action of Amino-Nogo is not specific for certain ECM substrates but may be specific for certain integrin receptor signaling pathways.

To determine which integrins mediate fibronectin-, laminin-, or collagen-dependent adhesion in COS-7 cells, we plated COS-7 cells onto fibronectin-, laminin-, or collagen-coated dishes in the presence of specific integrin-blocking antibodies. Integrin $\beta 1$ blocking antibodies abolished fibronectin- and laminindependent adhesion and reduced collagen-dependent adhesion by $80 \%$, suggesting that integrin $\beta 1$ is required for adhesion to all three ECM ligands (Fig. $2 E$ ). The presence of integrin $\alpha 5$ blocking antibody reduced the adhesion of COS-7 cells to fibronectin by $>80 \%$, but had no or minor effect on laminin- or collagen-dependent adhesion, suggesting that the principal integrin contributing to fibronectin adhesion in COS-7 cells is $\alpha 5 \beta 1$ 
A

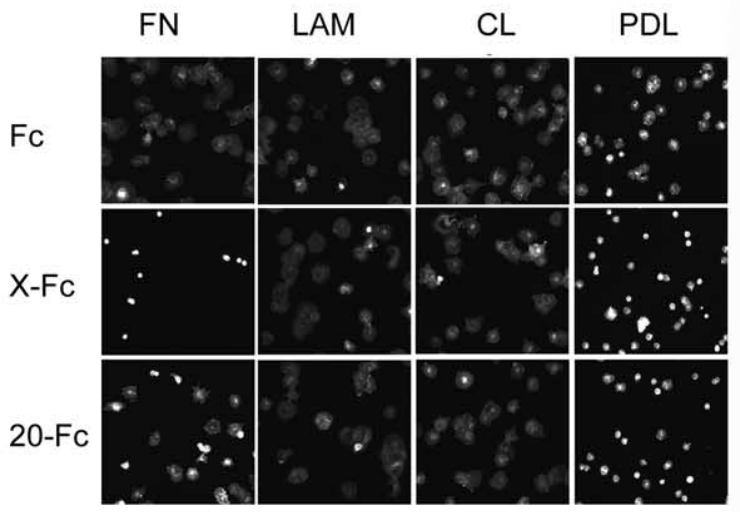

B

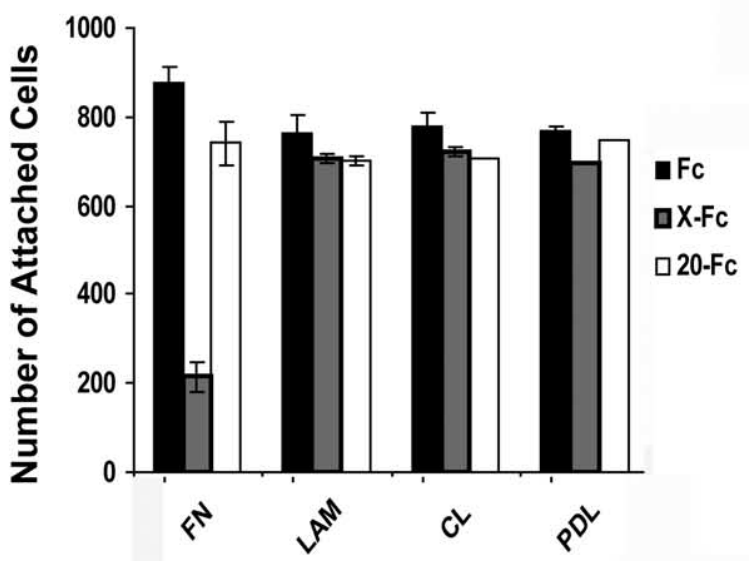

C



Figure 1. Amino-Nogo inhibits COS-7 adhesion on fibronectin, but not on laminin or collagen. $A$, Trypsinized COS-7 cells were plated on fibronectin- (FN; $1 \mu \mathrm{g} / \mathrm{ml}$ ), laminin- (LAM; 40 $\mu \mathrm{g} / \mathrm{ml}$ ), collagen- (CL; $50 \mu \mathrm{g} / \mathrm{ml}$ ), and poly-D-lysine (PDL; $100 \mu \mathrm{g} / \mathrm{ml}$ )-coated 96-well tissue culture dishes in the presence of $40 \mathrm{~nm} F c$ control, Fc fused Amino-Nogo X fragment (X-Fc), or $\Delta 20$ fragment $(\Delta 20-\mathrm{Fc}$ ) in DMEM. $B$, Quantification of number of attached cells for experiment in $\boldsymbol{A}$. C, Quantification of average cell area for experiment in $\boldsymbol{A}$.

(Fig. $2 E$ ). $\alpha 6 \beta 1$ integrin is the primary integrin receptor for laminin in COS-7 cells because integrin $\alpha 6$-blocking antibody almost abolished laminin-dependent adhesion in COS-7 cells (Fig. 2E). The integrin receptor for collagen is still not clear from this analysis. Because Amino-Nogo inhibits fibronectin adhesion but not laminin adhesion in COS-7 cells, the data show that $\alpha 5 \beta 1$ integrin-associated adhesion pathways but not $\alpha 6 \beta 1$ integrinassociated adhesion mechanisms are sensitive to Amino-Nogo inhibition.
A

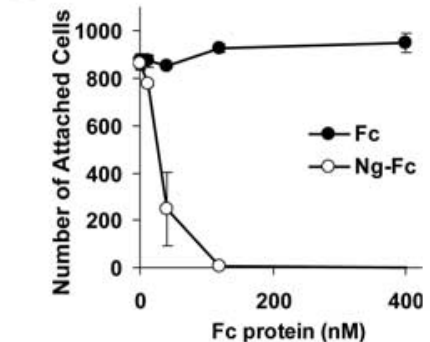

C

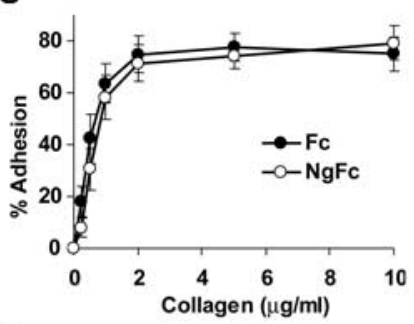

D
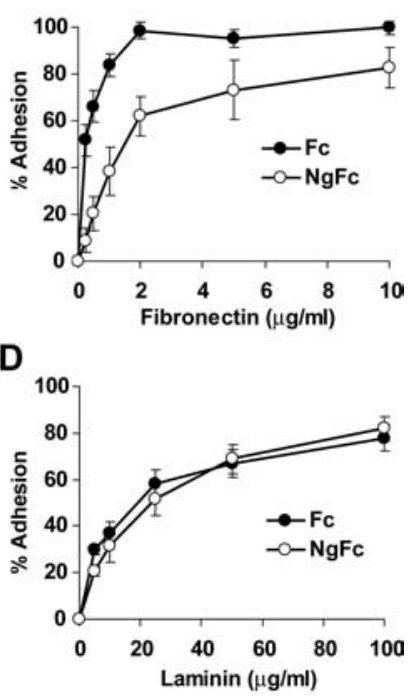

$\mathbf{E}$

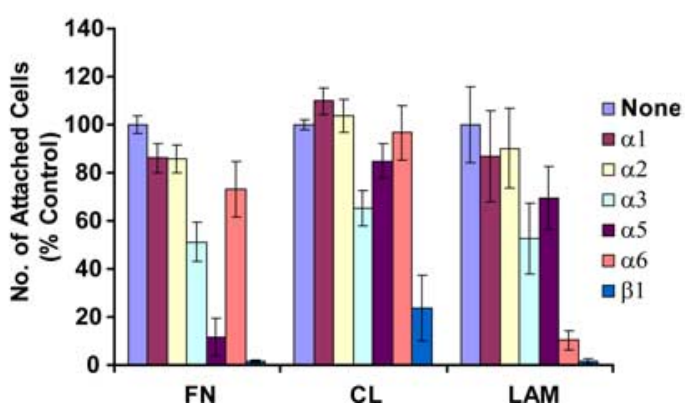

Figure 2. Dose-response curve of Amino-Nogo inhibition on COS-7 cells. A, Trypsinized COS-7 cells were plated on fibronectin $(1 \mu \mathrm{g} / \mathrm{ml})$-coated dishes in the presence of increasing concentration of clustered $\mathrm{Fc}$ or $\mathrm{Ng}-\mathrm{Fc}$ purified from insect cells. The number of attached cells was plotted as a function of $\mathrm{Fc}$ protein concentration. $\boldsymbol{B}$, The numbers of attached cells expressed as percentage of adhesion was plotted as a function of fibronectin concentration in the presence of $40 \mathrm{~nm}$ clustered $\mathrm{Fc}$ or $\mathrm{Ng}-\mathrm{Fc}$. C, The number of attached cells expressed as percentage of adhesion was plotted as a function of collagen concentrations in the presence of $40 \mathrm{~nm}$ clustered $\mathrm{Fc}$ or Ng-Fc. D, The number of attached cells expressed as percentage of adhesion was plotted as a function of laminin concentration in the presence of $40 \mathrm{~nm}$ clustered Fc or Ng-Fc. $\boldsymbol{E}$, Trypsinized COS-7 cells were plated on fibronectin- $(1 \mu \mathrm{g} / \mathrm{ml})$, collagen- $(1 \mu \mathrm{g} / \mathrm{ml})$, or laminin ( $20 \mu \mathrm{g} / \mathrm{ml})$-coated dishes in the presence of $20 \mu \mathrm{g} / \mathrm{ml}$ control, $\alpha 1$ integrin-blocking antibody Ha31/8 ( $\alpha 1), \alpha 2$ integrin-blocking antibody Ha1/29 ( $\alpha 2), \alpha 3$ integrin-blocking antibody P1B5 $(\alpha 3)$, a5 integrin-blocking antibody SAM-1 $(\alpha 5), \alpha 6$ integrin-blocking antibody GoH3 $(\alpha 6)$, or $\beta 1$ integrin-blocking antibody Ha2/5 ( $\beta 1)$. The number of attached cells was plotted as percentage of control in each condition.

Amino-Nogo inhibits integrin signaling

To further demonstrate that Amino-Nogo affects integrin signaling, we assessed whether downstream integrin signaling pathway is altered by Amino-Nogo. FAK is phosphorylated at tyrosine 397 when integrin is activated by ECM substrate. Amino-Nogo treatment significantly suppresses fibronectin-induced FAK activation in COS-7 cells compared with control (Fig. $3 A)(p<0.01$; $37 \%$ FAK activation in the presence of Amino-Nogo compared with control). These data further support the hypothesis that Amino-Nogo inhibits integrin signaling.

We next examined whether integrin activation can overcome Amino-Nogo inhibition. We tested the effect of integrinactivating antibodies and $\mathrm{Mn}^{2+}$ on Amino-Nogo inhibition. $\mathrm{Mn}^{2+}$ has been shown to enhance integrin-ligand interaction (Bazzoni et al., 1995, 1998). Both $\mathrm{Mn}^{2+}$ and integrin $\beta 1$ activating antibodies P4G11, HUTS4, and B44 can partially but 


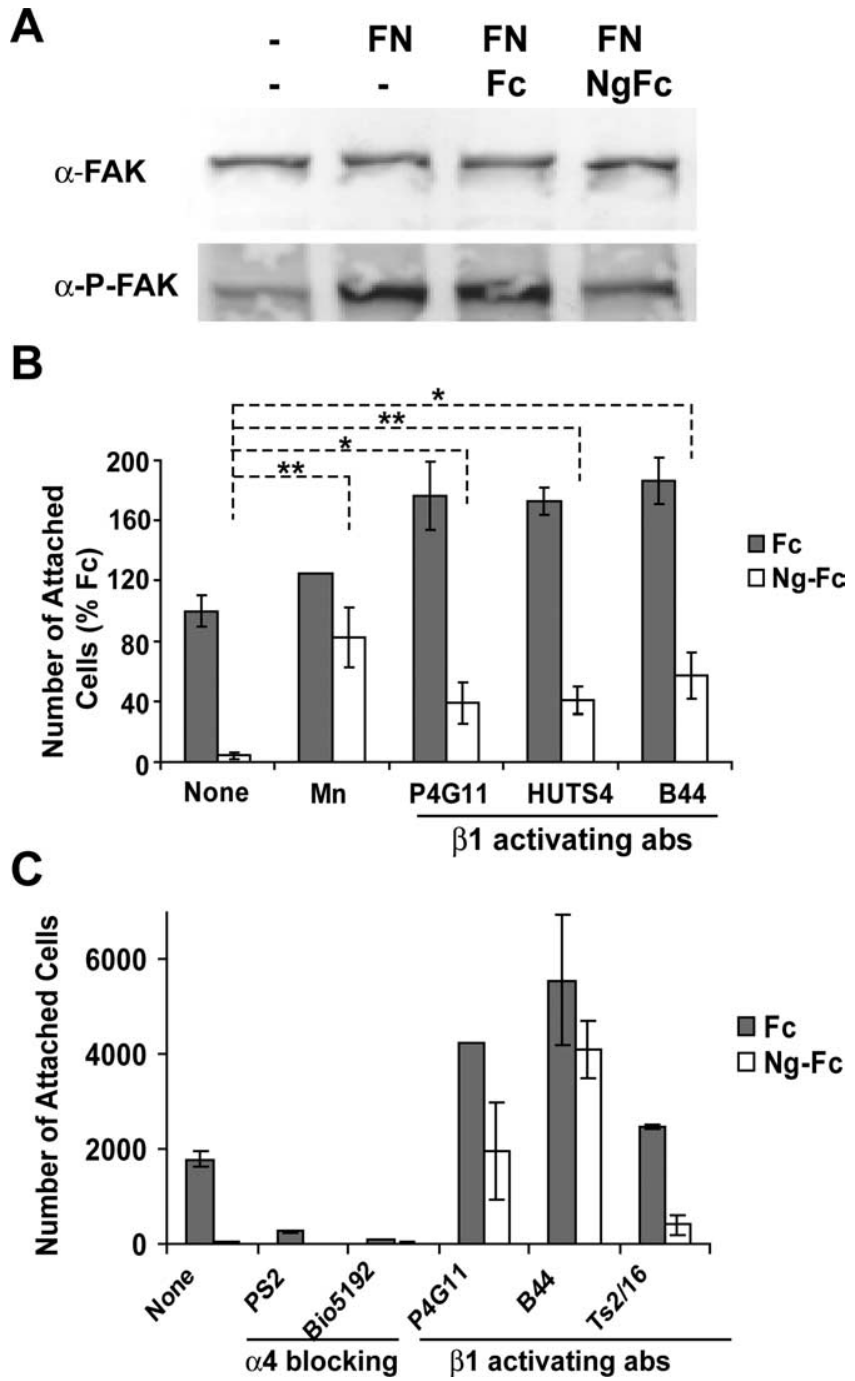

Figure 3. Amino-Nogo inhibits integrin signaling. $\boldsymbol{A}$, Amino-Nogo affects FAK activation. Trypsinized COS-7 cells were plated on BSA only (-) or fibronectin ( $5 \mu \mathrm{g} / \mathrm{ml} ; \mathrm{FN})$-coated dishes in the presence of PBS (-), $120 \mathrm{~nm} \mathrm{FC}$, or $120 \mathrm{~nm} \mathrm{Ng-Fc}$. Total FAK or phospho-FAK was analyzed using specific antibodies. $\boldsymbol{B}$, Integrin activation can partially overcome Amino-Nogo inhibition in COS-7 cells. Trypsinized COS-7 cells were plated on fibronectin ( $1 \mu \mathrm{g} / \mathrm{ml})$-coated dishes in the presence of $120 \mathrm{~nm} \mathrm{Fc}$ or Ng-Fc. $\mathrm{MnCl}_{2}(1 \mathrm{~mm})$ and $20 \mu \mathrm{g} / \mathrm{ml}$ indicated integrin $\beta 1$-activating antibodies were added when indicated. $C$, Integrin activation can partially overcome AminoNogo inhibition in Jurkat cells. Jurkat cells were plated on fibronectin $(10 \mu \mathrm{g} / \mathrm{ml})$-coated dishes in the presence of $40 \mathrm{~nm} \mathrm{Fc}$ or $\mathrm{Ng}-\mathrm{Fc}$. $\mathrm{MnCl}_{2}(1 \mathrm{~mm})$ and $20 \mu \mathrm{g} / \mathrm{ml}$ indicated integrin $\beta 1$ activating antibodies were added when indicated. Student's $s$ test revealed a significant difference in $\mathrm{MnCl}_{2}$ and $\beta 1$-activating antibodies treated conditions versus control condition $\left({ }^{*} p<\right.$ $0.05 ; * * 0.01)$.

significantly overcome Amino-Nogo inhibition of COS-7 adhesion on fibronectin (Fig. 3B), indicating that perturbation of integrin signaling plays an important role in Amino-Nogo inhibition.

\section{Integrins inhibited by Amino-Nogo}

Multiple integrins have been shown to mediate cell adhesion to fibronectin, including $\alpha 5 \beta 1, \alpha 4 \beta 1, \alpha \mathrm{v} \beta 1, \alpha \mathrm{v} \beta 3$, and $\alpha \operatorname{IIb} \beta 3$. To further determine integrin specificity of Amino-Nogo inhibition, we investigated the Amino-Nogo effect on adhesion by different cell lines. The adhesion of Jurkat T-cell on fibronectin has been shown to depend on $\alpha 4 \beta 1$ integrin and can be blocked by PS2, an $\alpha 4$ integrin-blocking antibody, or Bio5192, a small molecule inhibitor of $\alpha 4 \beta 1$ (Leone et al., 2003) (Fig. 3C). Amino-Nogo almost completely abolished Jurkat cell adhesion to fibronectin

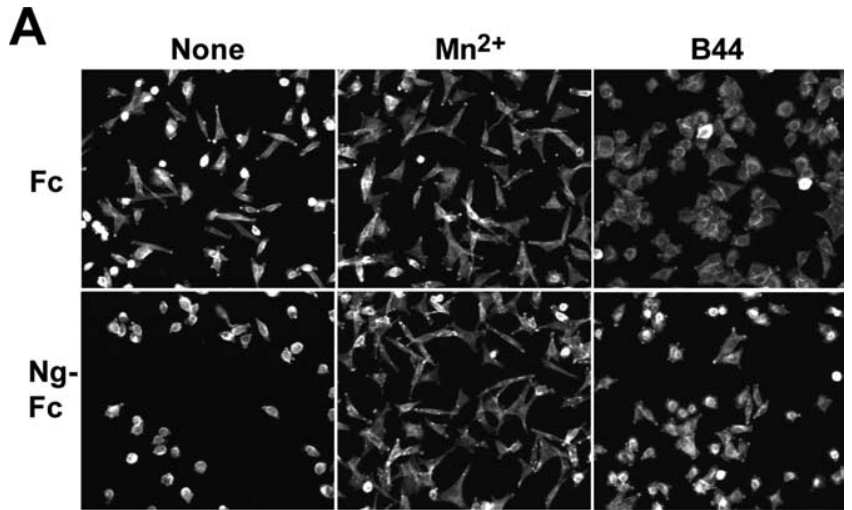

B

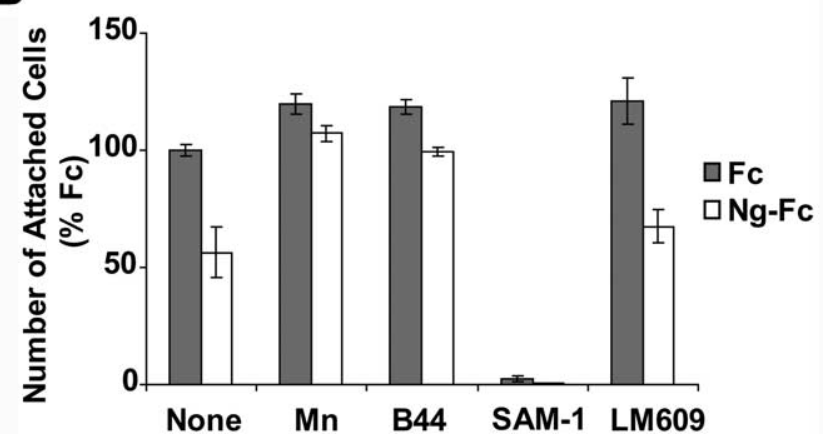

Figure 4. Amino-Nogo inhibits $\alpha 5$ integrin. $\boldsymbol{A}$, Amino-Nogo inhibits $\mathrm{CH} 0-\mathrm{K} 1$ adhesion on fibronectin. Trypsinized CH0-K1 cells were plated on fibronectin $(1 \mu \mathrm{g} / \mathrm{ml})$-coated dishes in the presence of $40 \mathrm{~nm} \mathrm{Fc}$ or $\mathrm{Ng}-\mathrm{Fc} . \mathrm{MnCl}_{2}(1 \mathrm{~mm})$ and $20 \mu \mathrm{g} / \mathrm{ml}$ indicated antibodies were added when indicated. $\boldsymbol{B}$, The number of attached cells was expressed as percentage of $\mathrm{Fc}$ control on fibronectin without $\mathrm{MnCl}_{2}$ or antibodies added.

(Fig. 3C), suggesting that $\alpha 4 \beta 1$ integrin signaling can be inhibited strongly by Amino-Nogo. Furthermore, antibodies that activate $\beta 1$ integrin, including P4G11, B44, and TS2/16 can substantially overcome Amino-Nogo effect (Fig. 3C), consistent with the data obtained from COS-7 cells.

To further confirm that $\alpha 5 \beta 1$ integrin can be inhibited by Amino-Nogo, we tested whether Amino-Nogo inhibits adhesion of CHO-K1 cells on fibronectin, because $\alpha 5 \beta 1$ integrin has been shown to be the major fibronectin receptor in $\mathrm{CHO}-\mathrm{K} 1$ cells (Schreiner et al., 1989). Indeed, antibodies that block $\alpha 5$ integrin (SAM-1) abolished adhesion of CHO-K1 cells on fibronectin, but blocking antibodies for $\alpha \mathrm{v} \beta 3$ integrin (LM609) did not do so (Fig. $4 \mathrm{~B}$ ). Amino-Nogo inhibits the attachment and spreading of $\mathrm{CHO}-\mathrm{K} 1$ cells on fibronectin, which can be overcome by the presence of $\mathrm{Mn}^{2+}$ and partially overcome by integrin $\beta 1$ activating antibody B44 (Fig. $4 A, B$ ). These data demonstrate that $\alpha 5 \beta 1$ integrin signaling is inhibited by Amino-Nogo.

To determine whether $\alpha \mathrm{v} \beta 3$ integrin is affected by AminoNogo, we examined the response of HUVEC cells to AminoNogo. Adhesion of HUVEC cells to vitronectin is known to depend on $\alpha v \beta 3$ integrin (Cheresh, 1987). Amino-Nogo reduced both the attachment and spreading of HUVEC cells on vitronectin, which can be overcome by the addition of $\mathrm{Mn}^{2+}$ (Fig. $5 A$ ). $\alpha v \beta 3$ integrin-blocking antibodies LM609 interfere with the adhesion of HUVEC cells on vitronectin, verifying the specificity of the response. A combination of LM609 and Amino-Nogo seems to have additive affect, suggesting that they inhibit $\alpha \mathrm{v} \beta 3$ integrin through different mechanisms (Fig. 5A). To further confirm that $\alpha v \beta 3$ integrin is inhibited by Amino-Nogo, we determined the response of CS1- $\beta 3$ cells to Amino-Nogo. CS1 is a hamster mel- 
A

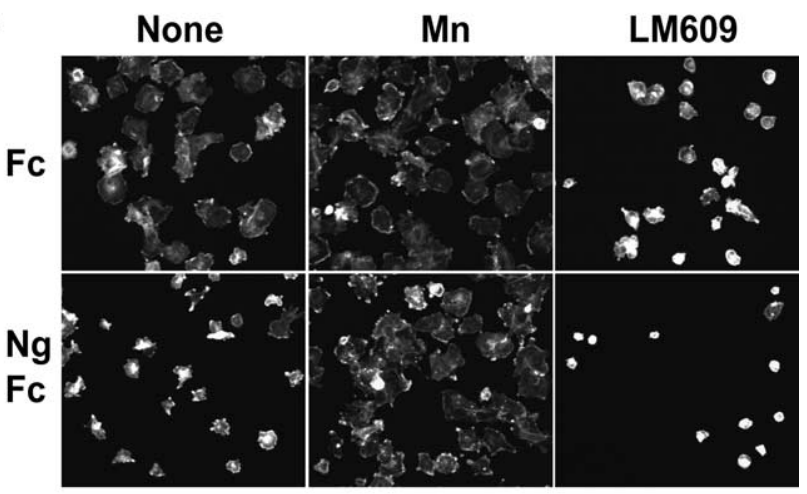

B

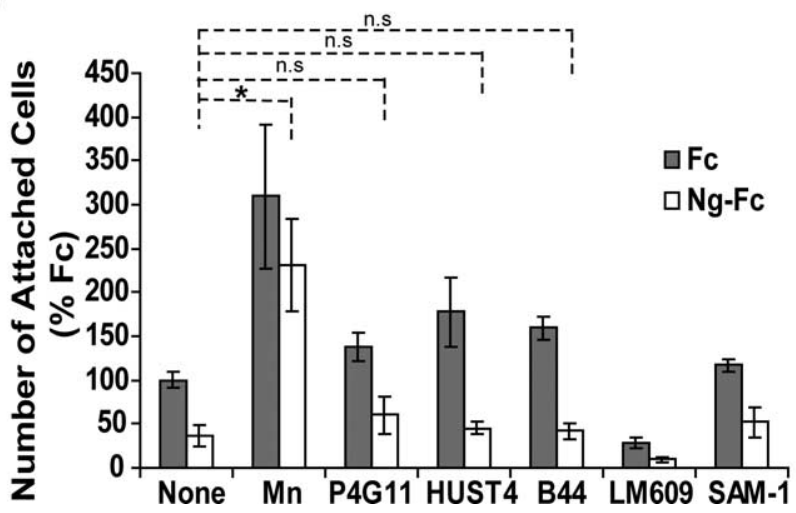

Figure 5. Amino-Nogo inhibits $\alpha v$ integrin. $\boldsymbol{A}$, Amino-Nogo inhibits HUVEC adhesion on vitronectin. Trypsinized HUVEC cells were plated on vitronectin $(1 \mu \mathrm{g} / \mathrm{ml})$-coated dishes in the presence of $40 \mathrm{~nm} \mathrm{Fc}$ or $\mathrm{Ng}-\mathrm{Fc}$. $\mathrm{MnCl}_{2}(1 \mathrm{~mm})$ and $20 \mu \mathrm{g} / \mathrm{ml}$ indicated antibodies were added when indicated. $\boldsymbol{B}$, Amino-Nogo inhibits CS1- $\beta 3$ adhesion on vitronectin. Trypsinized CS1- $\beta 3$ cells were plated on vitronectin (1 $\mu \mathrm{g} / \mathrm{ml})$-coated dishes in the presence of $40 \mathrm{~nm} \mathrm{Fc} \mathrm{or} \mathrm{Ng-Fc.}$ $\mathrm{MnCl}_{2}(1 \mathrm{~mm})$ and $20 \mu \mathrm{g} / \mathrm{ml}$ antibodies were added when indicated. Student's $t$ test showed a significant difference in $\mathrm{MnCl}_{2}$-treated conditions versus control condition $\left({ }^{*} p<0.05\right.$ ) but no significant difference (n.s.) in $\beta 1$-activating antibodies-treated condition.

anoma cell line that grows in suspension on vitronectin substrate (Thomas et al., 1993) because it lacks receptors for vitronectin. Transfection of $\beta 3$ integrin into CS1 allows these cells (CS1- $\beta 3$ ) to express functional vitronectin receptor $(\alpha \mathrm{v} \beta 3$ integrin) and attach to vitronectin (Filardo et al., 1995). Adhesion on vitronectin is dependent on $\alpha \mathrm{v} \beta 3$ integrin in CS1- $\beta 3$ cells, and can be blocked by LM609 antibodies (Fig. 5B). Amino-Nogo inhibits the attachment of CS1- $\beta 3$ cells on vitronectin by $60 \%$, which can be partially overcome by the presence of $\mathrm{Mn}^{2+}$ but not by integrin $\beta 1$-activating antibodies P4G11, HUST4, and B44 (Fig. 5B). Thus, $\alpha \mathrm{v} \beta 3$ integrin action is inhibited by Amino-Nogo in CS1- $\beta 3$ cells.

\section{Amino-Nogo inhibition on axon outgrowth is modulated by} ECM substrates

Amino-Nogo inhibits both cell adhesion and axon outgrowth. To determine whether Amino-Nogo inhibition of outgrowth also involves integrin inhibition, we examined whether Amino-Nogo inhibition of axon outgrowth can be modulated by ECM substrates. Neurons from embryonic cDRGs were plated onto fibronectin-, vitronectin-, laminin-, collagen-, or VCAM-1coated dishes in the presence of Fc control or Ng-Fc. VCAM-1 is a specific ligand for $\alpha 4$ integrin (Yusuf-Makagiansar et al., 2002), and there is evidence documenting expression of $\alpha 4$ integrin in DRG neurons and regenerating nerves (Vogelezang et al., 2001). We found that Amino-Nogo exhibits greater inhibitory activity on fibronectin, vitronectin, and VCAM-1 than on collagen or laminin (Fig. 6A,B). Amino-Nogo is strongly inhibitory on fibronectin and VCAM-1 at all the concentrations of fibronectin and VCAM-1 tested (Fig. 6 B). In contrast, Amino-Nogo inhibits neurons plated on low concentrations of laminin, but not on higher concentrations of laminin (Fig. 6B). The inhibition of neurons plated on collagen by Amino-Nogo shows similar concentration dependence (Fig. 6B). These data suggest that AminoNogo inhibition of outgrowth is also selective for certain integrin signaling pathways. A dose-response curve for Amino-Nogo inhibition on DRG neurons plated on fibronectin or VCAM-1 shows an $\mathrm{IC}_{50}$ of $\sim 40 \mathrm{~nm}$, similar to that in COS-7 cells (Fig. $6 \mathrm{C}$ ).

We repeated the outgrowth assay with postnatal rDRG neurons. Amino-Nogo shows greater inhibition of rDRG outgrowth on collagen or VCAM-1 than on fibronectin, laminin, or vitronectin (Fig. 6D). The differences between Amino-Nogo effect on COS-7, embryonic cDRG, and postnatal rDRG neurons is likely to be related to different integrin subunit expression levels in these types of cells. The presence of $\mathrm{Mn}^{2+}$ partially overcomes Amino-Nogo inhibition on fibronectin, collagen, and VCAM-1 (Fig. 6D), suggesting that integrin activation can overcome Amino-Nogo effect in axon outgrowth.

If the inhibition of DRG axon growth by Amino-Nogo is mediated by the reduced activation of certain integrins, then these ECM receptors should be found in DRG axons and growth cones. Indeed, immunohistologic analysis reveals the presence of at least $\alpha 5$ and $\alpha \mathrm{v}$ integrin subunits in the growth cones of chick DRG axons (Fig. 7A). Previous studies have demonstrated that $\beta 1$ integrin subunits are expressed in these axons (Tomaselli et al., 1993). Thus, integrins are available at the right context to be modulated by Amino-Nogo signaling.

\section{$\alpha 5$ and $\alpha v$ integrin expression in CNS}

The notion that Amino-Nogo contributes to limiting axonal growth in the adult CNS is supported by studies from Schwab and colleagues with antibodies directed against the Amino-Nogo (Liebscher et al., 2005; Freund et al., 2006). This led us to consider which integrin subunits that mediate Amino-Nogo-sensitive cell adhesion responses are available in the adult brain and spinal cord. Although $\alpha 4$ integrin expression has been reported in DRG neurons and regenerating sciatic nerves (Vogelezang et al., 2001), we failed to detect any discernible neuronal expression by immunofluorescence staining in the adult brain and spinal cord (data not shown). Thus, although $\alpha 4$ integrin can be inhibited by Amino-Nogo in vitro, this is unlikely to play a significant role in limiting adult CNS axonal growth in vivo. In contrast, both $\alpha 5$ integrin and $\alpha \mathrm{v}$ integrin have high and widespread expression in CNS (King et al., 2001) (Fig. 7B,C). Therefore, they provide likely sites for Amino-Nogo action in vivo.

\section{Nogo interacts physically with integrins}

Because Amino-Nogo inhibits integrin signaling, we asked whether there is physical interaction between Nogo and integrins. Brain lysates from wild-type or Nogo-A/B knock-out mice were subjected to immunoprecipitation (IP) using $\alpha \mathrm{v}$ and $\alpha 5$ integrin antibodies. Nogo-A protein is present in $\alpha \mathrm{v}, \alpha \mathrm{v} \beta 3$, and $\alpha 5$ integrin immunoprecipitates from wild-type brain lysates but not in control IgG immunoprecipitates (Fig. 7D), indicating that Nogo-A exists in a complex with these integrins in the brain. Nogo-A associates minimally if at all with integrin subunits under more stringent conditions in SDS-containing RIPA buffer (data not shown), suggesting an indirect and/or weak physical complex between Nogo-A and integrins. We failed to detect integrins in the anti-Nogo-A immunoprecipitates. It is quite likely 
A

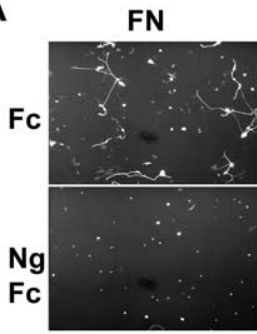

\section{VN}

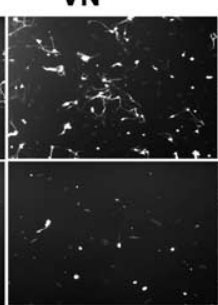

B

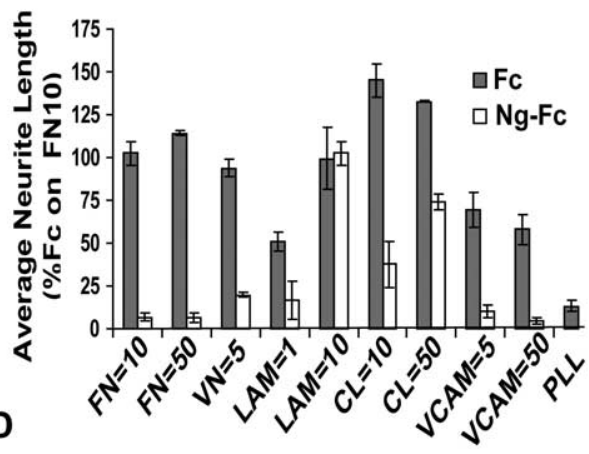

LAM

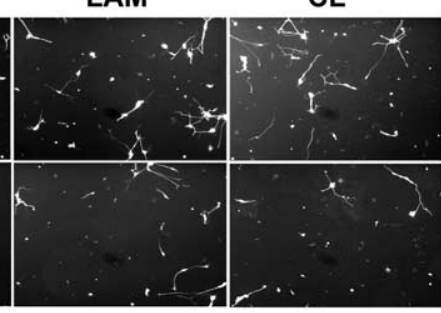

C

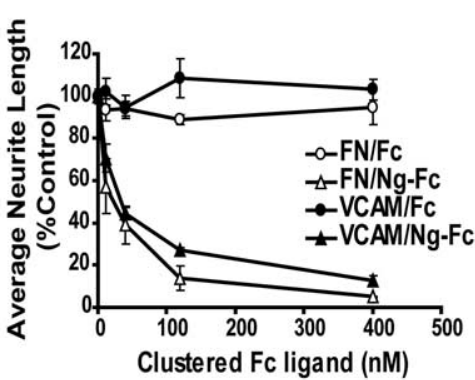

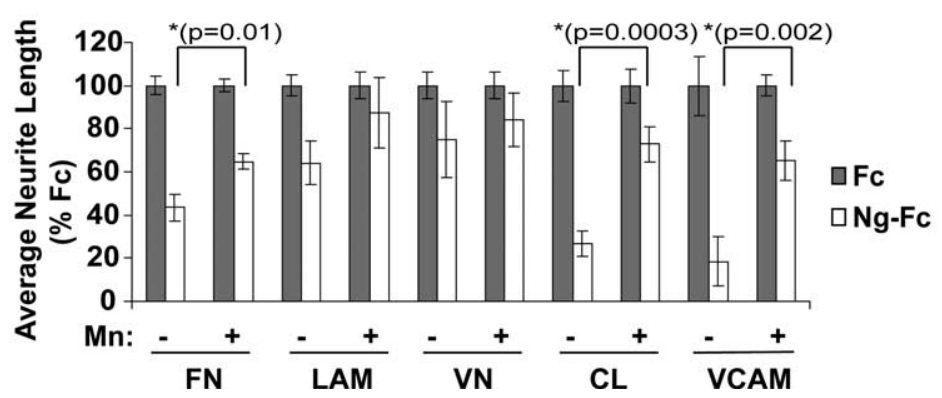

Figure 6. Amino-Nogo inhibition of axon outgrowth is modulated by ECM substrates. $\boldsymbol{A}$, Dissociated E9-E11 cDRGs neurons were plated on fibronectin $(10 \mu \mathrm{g} / \mathrm{ml})$, vitronectin $(5 \mu \mathrm{g} / \mathrm{ml})$, laminin $(10 \mu \mathrm{g} / \mathrm{ml})$, collagen $(50 \mu \mathrm{g} / \mathrm{ml})$, or VCAM-1 (5 $\mu \mathrm{g} / \mathrm{ml})$ coated 96-well tissue culture dishes in the presence of $40 \mathrm{~nm} \mathrm{Fc} \mathrm{or} \mathrm{Ng-Fc.} \mathrm{B,} \mathrm{Quantification} \mathrm{of} \mathrm{average} \mathrm{neurite} \mathrm{length} \mathrm{per} \mathrm{neuron}$ expressed as percentage of Fc control on fibronectin $10 \mu \mathrm{g} / \mathrm{ml}$ (FN10) for experiment in $\boldsymbol{A}$. Numbers indicate the concentration of ECM molecules used in each condition. C, Amino-Nogo inhibits CDRG outgrowth on fibronectin and VCAM-1 with IC $C_{50}$ of $\sim 40 \mathrm{~nm}$. Dissociated E9-E11 CDRGs neurons were plated on fibronectin- $(10 \mu \mathrm{g} / \mathrm{ml})$ or VCAM-1 (5 $\mu \mathrm{g} / \mathrm{ml})$-coated 96-well tissue culture dishes in the presence of increasing concentrations of Fc or $\mathrm{Ng}$-Fc. Average outgrowth per well in each condition was expressed as percentage of control and plotted as a function of Fc protein concentration. D, Amino-Nogo inhibits rDRG outgrowth on various ECM substrates. Dissociated p6-p10 rDRGs neurons were plated on ECM-coated 96-well tissue culture dishes as indicated. $\mathrm{MnCl}_{2}$ $(1 \mathrm{~mm})$ was added when indicated ( + ). Average outgrowth per well in each condition was expressed as percentage of Fc control. $p$ values are calculated using two-tailed Student's $t$ test.

that the anti-Nogo-A antibodies used for IP disrupted the Nogointegrin interaction because the antigenic peptide is within the active region of Amino-Nogo (Wang et al., 2002). A monoclonal antibody (11B7) recognizing the same peptide is known to be functional in vivo and to improve regeneration and locomotion of spinal cord-injured rats (Liebscher et al., 2005).

Although Amino-Nogo and integrins form a complex in brain, the interaction may or may not require other intermediate proteins. Purified Amino-Nogo and integrins were tested for a direct interaction in an ELISA format. No direct binding was detected under these conditions (data not shown). It is possible that the extracted and purified integrins have lost a conformation capable of Amino-Nogo binding or that the association between integrin and Nogo is mediated through a protein or protein complex present in many cell types.

\section{Discussion}

In this study, we demonstrate that perturbation of integrin signaling mediates Amino-Nogo inhibition of cell adhesion and

axon outgrowth. First, inhibition of COS-7 adhesion by Amino-Nogo is selective for fibronectin. Second, Amino-Nogo affects FAK activation on fibronectin, and AminoNogo inhibition of cell adhesion can be partially overcome by integrin activation. Third, we demonstrate that Amino-Nogo can inhibit $\alpha 4 \beta 1-, \quad \alpha 5-$, and $\alpha \mathrm{v} \beta 3$ integrindependent adhesion, but not $\alpha 6 \beta 1$ integrindependent adhesion. Fourth, Amino-Nogo inhibition of axon outgrowth can also be modulated by ECM substrates and partially overcome by integrin activator $\mathrm{Mn}^{2+}$, suggesting that Amino-Nogo inhibition of axon outgrowth also involves inhibition of integrin signaling. Brain $\alpha 5$ and $\alpha \mathrm{v}$ integrin subunits may interact indirectly with Nogo-A as part of a larger protein complex.

\section{Integrin specificity of}

Amino-Nogo inhibition

Amino-Nogo inhibition is specific for certain integrin signaling pathways. In COS-7 cells, fibronectin-dependent adhesion mediated by integrin $\alpha 5 \beta 1$ is eliminated by Amino-Nogo, but laminin- or collagendependent adhesion is essentially unaffected. Because $\alpha 6 \beta 1$ integrin mediates laminin-dependent adhesion, this analysis suggests that $\alpha 6 \beta 1$ integrin is resistant to Amino-Nogo inhibition, whereas the fibronectin-interacting $\alpha 5 \beta 1$ integrindependent adhesion pathway is sensitive. Analysis of Amino-Nogo action in several other cell lines demonstrates that the adhesion pathways requiring integrins $\alpha 4 \beta 1$, $\alpha 5 \beta 1$, and $\alpha \mathrm{v} \beta 3$ are sensitive to AminoNogo inhibition. $\quad \alpha 4 \beta 1$ integrindependent adhesion probably is most sensitive to Amino-Nogo effect because Amino-Nogo inhibits 90\% of Jurkat cell adhesion to fibronectin and $\sim 80 \%$ of VCAM-1-dependent outgrowth.

Although laminin and collagen receptors on COS-7 cells are resistant to AminoNogo inhibition, there are some laminin and collagen receptors sensitive to Amino-Nogo. DRG neurons are inhibited by AminoNogo when cultured on a collagen substrate or on a laminin substrate. PC12 cells are sensitive to Amino-Nogo on fibronectin, laminin, or collagen substrates (data not shown). Thus, sensitivity to Amino-Nogo is determined by the expression pattern of ECM receptors on the cell surface. Complete analysis of the multiple ECM receptors expressed on various cell lines and DRG neurons will define the spectrum of Amino-Nogo inhibition.

\section{Mechanisms of Amino-Nogo inhibition}

We demonstrate that Amino-Nogo physically interacts with $\alpha 5$ and $\alpha \mathrm{v}$ integrins of adult brain, raising the possibility that Amino-Nogo might inhibit integrin function through direct binding. However, purified Amino-Nogo and integrin did not exhibit significant affinity for one another (data not shown). The conformation of purified, detergent-extracted integrins might not be optimal for binding to Nogo, or alternatively, other pro- 
A

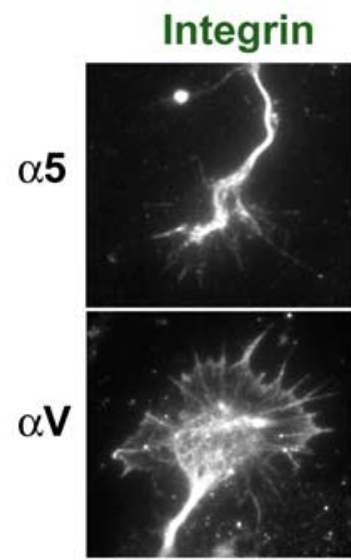

C

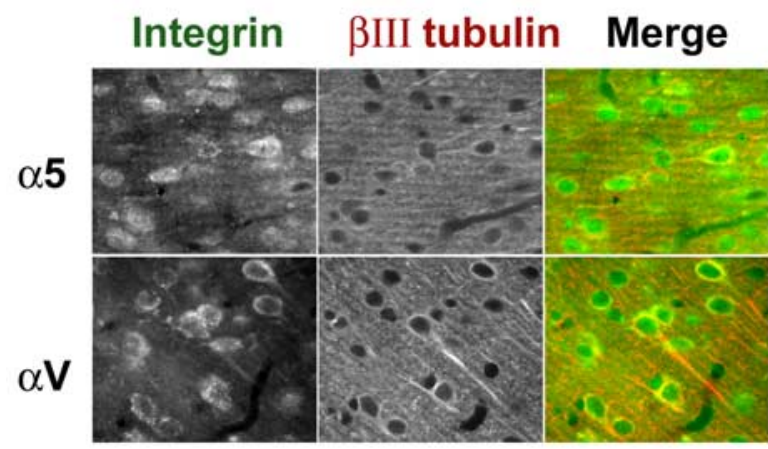

B

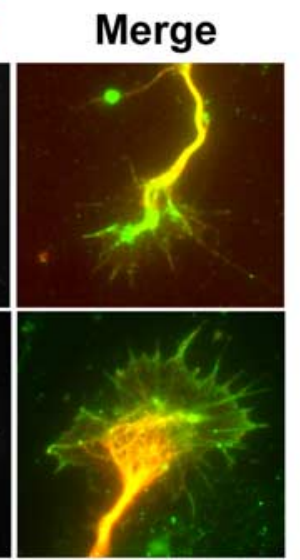

D

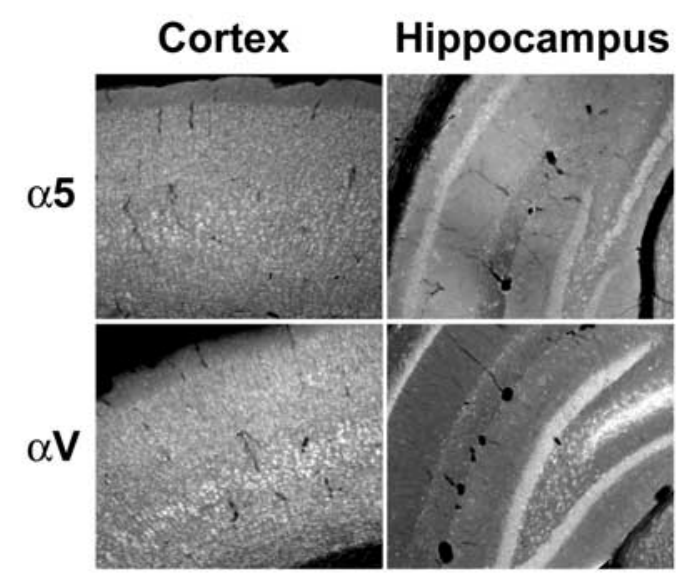

WT

KO

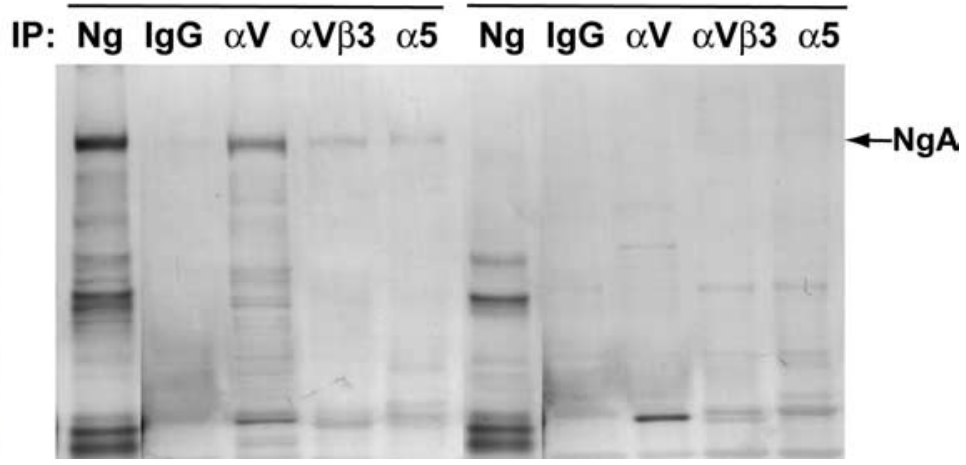

Figure 7. Amino-Nogo expression in growth cones and CNS. $\boldsymbol{A}$, Immunofluorescence staining of $\alpha \mathrm{V}$ and $\alpha 5$ integrin in E10 CDRG growth cones with integrin staining in green and $\beta$ III tubulin staining in red. $\boldsymbol{B}$, Immunofluorescence staining of $\alpha \mathrm{v}$ and $\alpha 5$ integrin in adult mouse brain cortex and hippocampus. $\boldsymbol{C}$, Immunofluorescence staining of $\alpha \mathrm{V}$ and $\alpha 5$ integrin in adult mouse brain cortex with integrin staining in green and $\beta$ III tubulin staining in red. $\boldsymbol{D}$, Nogo interacts with integrins in the brain. Adult wild-type (WT) or nogoAB $-/-(K 0)$ mouse brain lysates were immunoprecipitated in Triton X-100-containing buffer using rabbit anti-Nogo- $\mathrm{A}$, rat lgG, rat anti- $\alpha \mathrm{v}$ integrin, mouse anti- $\alpha \mathrm{v} \beta 3$ integrin, or mouse anti- $\alpha 5$ integrin antibodies. The presence of Nogo was detected using anti-Nogo-A antibodies ( $\mathrm{NgA})$.

teins might be required to mediate the functional interactions between Nogo and integrins. Association of Nogo to integrin, whether direct or indirect, might reduce the binding affinity of integrin for its ligands. Consistent with this model, increasing concentrations of ECM ligands can overcome Amino-Nogo inhibition in several cases (Figs. $2 B, 6 B$ ).

If Nogo-A alters the function of certain integrin subunits indirectly, this might occur via either novel cell surface-binding sites or a nonintegrin cell adhesion receptor. Cell adhesion is a cooperative process known to involve both integrin and nonintegrin receptors, so it is likely that nonintegrin adhesion receptors play a role even in cases such as COS-7 adhesion to fibronectin, in which anti- $\alpha 5$ integrin receptor antibodies abolish adhesion. However, if nonintegrin receptors do play a role in mediating Nogo-A action, they must obey strict integrin subunit-defined specificities of adhesion, for example, with no effect on $\alpha 6$ integrin-dependent adhesion to laminin.

One study indicated that Amino-Nogo activates Rho-A (Niederost et al., 2002), whereas another study did not observe RhoA activation (Fournier et al., 2003). The Rho signaling pathway has been shown to influence the dynamics of integrindependent adhesion sites known as point contacts at the growth cones (Woo and Gomez, 2006). The relationship between Rho activation and inhibition of integrin signaling by Amino-Nogo remains to be determined.
In vivo significance of Amino-Nogo inhibition of integrin signaling

At least two integrin subunits ( $\alpha 5$ and $\alpha \mathrm{v}$ ), which are sensitive to Amino-Nogo inhibition, are widely expressed in the adult CNS. It is well known that integrins have extremely robust effects on in vitro growth of embryonic neurons, and the vast majority of outgrowth assays in the literature have been performed under conditions that depend heavily on integrin function (Condic and Letourneau, 1997). In the adult CNS, there are few data addressing a potential role for integrins in mediating axonal growth over long distances (Condic, 2001). The connection of certain integrins with Amino-Nogo inhibition enhances the need for specific studies of integrin function in axonal regeneration and recovery after CNS injury. It is recognized that adult brain synaptic plasticity can be regulated by integrin interaction with a range of ligands, including reelin, HB-GAM (heparin-binding growthassociated molecule), Narp (neuronal activity-regulated pentraxin), tenascins, and chondroitin sulfate proteoglycans (for review, see Dityatev and Schachner, 2003). At sites of adult CNS injury, several ECM integrin ligands are strongly expressed. Astrocyte-associated fibronectin is critical for axon regeneration in adult white matter (Tom et al., 2004). Injury-site specific fibronectin may be generated by brain microglia and/or invading meningeal fibroblasts (supplemental Fig. 1, available at www. jneurosci.org as supplemental material) (Egan and Vijayan, 
1991). Laminin is also present at CNS trauma sites (supplemental Fig. 1, available at www.jneurosci.org as supplemental material).

Nogo-A limitation of axonal growth in the adult CNS appears to function by two independent signaling pathways. The Nogo-66 domain enhanced by an adjacent binding site stimulates $\mathrm{NgR}$ in concert with the myelin proteins MAG and OMgp ( $\mathrm{Hu}$ et al., 2005). The Amino-Nogo domain inhibition of integrin function demonstrated here is independent of this pathway. Peptide, antibody, and protein therapeutics have targeted various aspects of the Nogo/NgR pathway successfully to promote improved recovery from spinal cord injury and stroke in preclinical studies (Lee et al., 2003; Liu et al., 2006). The Amino-Nogo-sensitive integrin subunits and their ECM ligands contribute additional sites to develop therapeutic approaches to stimulate axonal growth and behavioral recovery from adult neurological deficits. Such agents may be expected to function synergistically with Nogo-66/MAG/OMgp/NgR directed reagents.

\section{References}

Bazzoni G, Shih DT, Buck CA, Hemler ME (1995) Monoclonal antibody 9EG7 defines a novel beta 1 integrin epitope induced by soluble ligand and manganese, but inhibited by calcium. J Biol Chem 270:25570-25577.

Bazzoni G, Ma L, Blue ML, Hemler ME (1998) Divalent cations and ligands induce conformational changes that are highly divergent among beta1 integrins. J Biol Chem 273:6670-6678.

Beningo KA, Dembo M, Kaverina I, Small JV, Wang YL (2001) Nascent focal adhesions are responsible for the generation of strong propulsive forces in migrating fibroblasts. J Cell Biol 153:881-888.

Bregman BS, Kunkel-Bagden E, Schnell L, Dai HN, Gao D, Schwab ME (1995) Recovery from spinal cord injury mediated by antibodies to neurite growth inhibitors. Nature 378:498-501.

Chen MS, Huber AB, van der Haar ME, Frank M, Schnell L, Spillmann AA, Christ F, Schwab ME (2000) Nogo-A is a myelin-associated neurite outgrowth inhibitor and an antigen for monoclonal antibody IN-1. Nature 403:434-439.

Cheresh DA (1987) Human endothelial cells synthesize and express an ArgGly-Asp-directed adhesion receptor involved in attachment to fibrinogen and von Willebrand factor. Proc Natl Acad Sci USA 84:6471-6475.

Condic ML (2001) Adult neuronal regeneration induced by transgenic integrin expression. J Neurosci 21:4782-4788.

Condic ML, Letourneau PC (1997) Ligand-induced changes in integrin expression regulate neuronal adhesion and neurite outgrowth. Nature 389:852-856.

Dityatev A, Schachner M (2003) Extracellular matrix molecules and synaptic plasticity. Nat Rev Neurosci 4:456-468.

Egan RA, Vijayan VK (1991) Fibronectin immunoreactivity in neural trauma. Brain Res 568:330-334.

Filardo EJ, Brooks PC, Deming SL, Damsky C, Cheresh DA (1995) Requirement of the NPXY motif in the integrin beta 3 subunit cytoplasmic tail for melanoma cell migration in vitro and in vivo. J Cell Biol 130:441-450.

Fournier AE, GrandPre T, Strittmatter SM (2001) Identification of a receptor mediating Nogo-66 inhibition of axonal regeneration. Nature 409:341-346.

Fournier AE, Takizawa BT, Strittmatter SM (2003) Rho kinase inhibition enhances axonal regeneration in the injured CNS. J Neurosci 23:1416-1423.

Freund P, Schmidlin E, Wannier T, Bloch J, Mir A, Schwab ME, Rouiller EM (2006) Nogo-A-specific antibody treatment enhances sprouting and functional recovery after cervical lesion in adult primates. Nat Med 12:790-792.

GrandPre T, Nakamura F, Vartanian T, Strittmatter SM (2000) Identification of the Nogo inhibitor of axon regeneration as a Reticulon protein. Nature 403:439-444.

Hu F, Liu BP, Budel S, Liao J, Chin J, Fournier A, Strittmatter SM (2005) Nogo-A interacts with the Nogo-66 receptor through multiple sites to create an isoform-selective subnanomolar agonist. J Neurosci 25:5298-5304.
Huber AB, Schwab ME (2000) Nogo-A, a potent inhibitor of neurite outgrowth and regeneration. Biol Chem 381:407-419.

Hynes RO (1992) Integrins: versatility, modulation, and signaling in cell adhesion. Cell 69:11-25.

Kim JE, Li S, GrandPre T, Qiu D, Strittmatter SM (2003) Axon regeneration in young adult mice lacking Nogo-A/B. Neuron 38:187-199.

King VR, McBride A, Priestley JV (2001) Immunohistochemical expression of the alpha5 integrin subunit in the normal adult rat central nervous system. J Neurocytol 30:243-252.

Lee DH, Strittmatter SM, Sah DW (2003) Targeting the Nogo receptor to treat central nervous system injuries. Nat Rev Drug Discov 2:872-878.

Leone DR, Giza K, Gill A, Dolinski BM, Yang W, Perper S, Scott DM, Lee WC, Cornebise M, Wortham K, Nickerson-Nutter C, Chen LL, LePage D, Spell JC, Whalley ET, Petter RC, Adams SP, Lobb RR, Pepinsky RB (2003) An assessment of the mechanistic differences between two integrin alpha 4 beta 1 inhibitors, the monoclonal antibody TA-2 and the small molecule BIO5192, in rat experimental autoimmune encephalomyelitis. J Pharmacol Exp Ther 305:1150-1162.

Liebscher T, Schnell L, Schnell D, Scholl J, Schneider R, Gullo M, Fouad K, Mir A, Rausch M, Kindler D, Hamers FP, Schwab ME (2005) Nogo-A antibody improves regeneration and locomotion of spinal cord-injured rats. Ann Neurol 58:706-719.

Liu BP, Cafferty WB, Budel SO, Strittmatter SM (2006) Extracellular regulators of axonal growth in the adult central nervous system. Philos Trans R Soc Lond B Biol Sci 361:1593-1610.

Niederost B, Oertle T, Fritsche J, McKinney RA, Bandtlow CE (2002) Nogo-A and myelin-associated glycoprotein mediate neurite growth inhibition by antagonistic regulation of RhoA and Racl. J Neurosci 22:10368-10376.

Oertle T, van der Haar ME, Bandtlow CE, Robeva A, Burfeind P, Buss A, Huber AB, Simonen M, Schnell L, Brosamle C, Kaupmann K, Vallon R, Schwab ME (2003) Nogo-A inhibits neurite outgrowth and cell spreading with three discrete regions. J Neurosci 23:5393-5406.

Robles E, Gomez TM (2006) Focal adhesion kinase signaling at sites of integrin-mediated adhesion controls axon pathfinding. Nat Neurosci $1274-1283$.

Schreiner CL, Bauer JS, Danilov YN, Hussein S, Sczekan MM, Juliano RL (1989) Isolation and characterization of Chinese hamster ovary cell variants deficient in the expression of fibronectin receptor. J Cell Biol 109:3157-3167.

Suter DM, Forscher P (1998) An emerging link between cytoskeletal dynamics and cell adhesion molecules in growth cone guidance. Curr Opin Neurobiol 8:106-116.

Thallmair M, Metz GA, Z'Graggen WJ, Raineteau O, Kartje GL, Schwab ME (1998) Neurite growth inhibitors restrict plasticity and functional recovery following corticospinal tract lesions. Nat Neurosci 1:124-131.

Thomas L, Chan PW, Chang S, Damsky C (1993) 5-Bromo-2-deoxyuridine regulates invasiveness and expression of integrins and matrix-degrading proteinases in a differentiated hamster melanoma cell. J Cell Sci 105:191-201.

Tom VJ, Doller CM, Malouf AT, Silver J (2004) Astrocyte-associated fibronectin is critical for axonal regeneration in adult white matter. J Neurosci 24:9282-9290.

Tomaselli KJ, Doherty P, Emmett CJ, Damsky CH, Walsh FS, Reichardt LF (1993) Expression of beta 1 integrins in sensory neurons of the dorsal root ganglion and their functions in neurite outgrowth on two laminin isoforms. J Neurosci 13:4880-4888.

Vogelezang MG, Liu Z, Relvas JB, Raivich G, Scherer SS, ffrench-Constant C (2001) Alpha4 integrin is expressed during peripheral nerve regeneration and enhances neurite outgrowth. J Neurosci 21:6732-6744.

Wang X, Chun SJ, Treloar H, Vartanian T, Greer CA, Strittmatter SM (2002) Localization of Nogo-A and Nogo-66 receptor proteins at sites of axonmyelin and synaptic contact. J Neurosci 22:5505-5515.

Woo S, Gomez TM (2006) Racl and RhoA promote neurite outgrowth through formation and stabilization of growth cone point contacts. J Neurosci 26:1418-1428.

Yusuf-Makagiansar H, Anderson ME, Yakovleva TV, Murray JS, Siahaan TJ (2002) Inhibition of LFA-1/ICAM-1 and VLA-4/VCAM-1 as a therapeutic approach to inflammation and autoimmune diseases. Med Res Rev 22:146-167. 